УДК 343.982 .3

DOI https://doi.org/10.32849/2663-5313/2020.1.37

Костянтин Дубонос,

аспірант кафедри криміналістичного забезпечення та судових експертиз

Національної академії внутрішніх справ

\title{
МОЖЛИВОСТІ ЗАПРОВАДЖЕННЯ ЦИФРОВИХ ТЕХНОЛОГІЙ ПІД ЧАС ЗБИРАННЯ, ОБРОБКИ ТА АНАЛІЗУ БІОМЕТРИЧНИХ ДАНИХ У ПІДРОЗДІЛАХ ЕКСПЕРТНОЇ СЛУЖБИ МВС УКРАЇНИ
}

У статті зазначається, що одним із напрямів удосконалення використання біометричних даних під час розслідування кримінальних правопорушень є запровадження иифрових технологій у процес збирання та накопичення біометричних даних, а також наповнення та використання баз біометричних даних. Визначаються можливості запровадження иифрових технологій у процес збирання, обробки й аналізу біометричних даних у підрозділах Експертної служби МВС України. З'ясовано, що підрозділи Експертної служби МВС України під час збирання, обробки й аналізу дактилоскопічної інформаиії також використовують сканери відбитків пальиів рук. Пристрої для читання відбитків пальиів рук зараз знаходять різні застосування. Їх встановлюють на ноутбуки, в комп'ютерні миші, клавіатури, флешки, а також застосовують у вигляді окремих зовнішніх пристроїв і терміналів, що продаються в комплекті із системами AFIS. Визначено, що для дослідження загальних і окремих ознак використовуються різні програмні засоби. Одним з істотних переваг, які вони надають, $є$ найиириі можливості роботи з иифровими зображеннями слідів. Масштабування, обертання по осях, регулювання контрасту, яскравості, застосування різного роду фільтрів зображень, переведення у негативне зображення, накладення сітки, вимірювань лінійних і кутових величин і багато іншого, що, безумовно, полегшує проведення візуального дослідження. Значно спрошуються і підрахунок ліній, а також загальної кількості окремих ознак, створення розробки сліду. Зроблено висновок, що оптимізаиія проиесу збирання, обробки та аналізу біометричних даних підрозділами Експертної служби МВС України неможлива без урахування досягнень науково-технічного прогресу. Одним із напрямком удосконалення використання біометричних даних під час розслідування кримінальних правопорушень є запровадження иифрових технологій у процес збирання та накопичення біометричних даних, а також наповнення та використання баз біометричних даних. Використання підрозділами Експертної служби МВС України иифрових технологій у роботі з біометричними даними дозволить підвищити кількісні й якісні показники отриманих даних; зменшити витрати часу на їх збирання, дослідження та кримінальну реєстрачію; автоматизувати їх дослідження; підвищити ймовірність ідентифікаиї за ними особи.

Ключові слова: бази біометричних даних, Експертна служба МВС України, інформаційнодовідкове забезпечення розслідування, цифрові технології, збирання, обробка, аналіз.

Постановка проблеми. У сучасному світовому просторі цифрові технології $€$ найдинамічнішою сферою за показниками власного розвитку [1, с. 79]. При цьому їх використання активно запроваджується в різні сфери суспільного життя. Однією з таких галузей є правоохоронна та судовоекспертна діяльність. Адже, як цілком слушного 3 цього приводу вказують В.П. Бахін i В.А. Заруцький, розвиток криміналістики в умовах бурхливого науково-технічного прогресу забезпечує суттєве розширення можливостей використання технічних засобів і методів для збирання та дослідження інформації з метою розслідування і попередження злочинів. Більше того, застосування складних технічних комплексів дає можливість не лише вдосконалити, а й підняти на якісно новий рівень традиційні методики виявлення, фіксації та обробки криміналістично значущої інформації [2, с. 36-41; 3, c. 93].

3 вищезазначеного випливає, що запровадження цифрових технологій у правоохоронну та судово-експертну діяльність дозволяє оптимізувати та підвищити якість збирання, оцінки, дослідження та використання доказів у кримінальному провадженні. 
Якщо ж урахувати розвиток біометричних технологій і їх використання в процесі виявлення, розкриття та розслідування кримінальних правопорушень, то особливо актуальним видається питання можливостей запровадження цифрових технологій під час збирання, обробки та аналізу біометричних даних у підрозділах Експертної служби МВС України.

Аналіз останніх досліджень. Питання формування та використання інформаційних систем як елемента інформаційно-довідкового забезпечення досудового розслідування кримінальних правопорушень неодноразово досліджувалися в працях таких учених, як: Р. С. Бєлкіна, В. В. Бірюкова, А. Е. Волкової, Д. В. Дабіжи, В. А. Журавля, Є. П. Іщенка, В. В. Лисенка, С. Д. Лук'янчикова, С. А. Ялишева й інших. Однак указані напрацювання в основному стосуються загальних положень кримінальної реєстрації, рівнів і видів криміналістичних обліків. Разом із тим поза увагою залишені особливості використання цифрових технологій у їх наповненні та використанні, переваги запровадження таких технологій у діяльність зі збирання, обробки й аналізу біометричних даних у підрозділах Експертної служби МВС України.

Мета статті висвітлити можливості використання цифрових технологій під час збирання, обробки й аналізу таких біометричних даних, як дактилоскопічна та геномна інформація, ознаки голосів і мовлення людини.

Виклад основного матеріалу. Під час збирання, обробки й аналізу дактилоскопічної інформації підрозділами Експертної служби МВС України використовуються сучасні криміналістичні засоби виявлення фіксації, вилучення та дослідження слідів рук. Як вказує А. С. Мокляк, на сучасному етапі розвитку криміналістичних лабораторій системи МВС України стрімко почала оновлюватись техніка та збільшилось фінансування на закупівлю необхідного обладнання та реактивів. За останні два роки в більшості Науково-дослідних експертнокриміналістичних центрів МВС України, зокрема у дактилоскопічних лабораторіях, були встановлені уніфіковані дактилоскопічні бокси «ДАКТОБОКС ЕКСПЕРТ 100», «DFC100-DFC200». Заміна старого й закупівля нового обладнання не лише покращила швидкість виконання експертних завдань, а й підвищила рівень якості виявлення слідів рук. Стандартизація нових приладів дозволяє використовувати висновки експертів у якісно новому рівні доказування, де імовірність хибного висновку буде зводитися виключно до людського фактору [4, с. 134].
На озброєнні працівників підрозділів Експертної служби МВС України є такі цифрові технології, як:

- сучасний цифровий мікроскоп LEICA DVM6, який є високо інтегрованою цифровою мікроскопічною системою, що поєднала незрівнянну якість зображення і швидкість зйомки. Цифровий мікроскоп «Leica DVM6» дозволяє проводити тривимірне сканування об'єктів, досліджувати деталі під різними кутами в межах від $25^{\circ}$ до $55^{\circ}$ з можливістю повороту системи відносно зразка на $360^{\circ}$. Перевагою цифрового мікроскопа Leica DVM6 є наявність програмного забезпечення LAS X, яке дозволяє проводити вимірювання 2D, 3D, анотації, різні виміри, та програмного модуля для створення багатофокусних зображень і зшивання зображень по XYZ. Результати можуть бути проаналізовані в 2D i 3D. Експорт результатів в шаблон для звітів Excel виконується одним натисканням. Завдяки непомітному зчитуванню значень у разі збільшення масштабу та положення об'єктива, а також застосуванню правильного калібрування забезпечується максимальна надійність вимірювань зображення. Крім того, для кожного зображення зберігається та відображається величина його загального збільшення;

- цифровий мікроскоп Sigeta Expert 10-300x - це сучасний професійний прилад для дослідження дрібних предметів у збільшеному зображенні в діапазоні від 10 до 300 разів, оснащений 5-мегапіксельною камерою, яка підтримує формати зображень JPG і відео формат AVI. Мікроскоп дозволяе отримувати знімки високої якості та роздільної здатності. Підключається до комп'ютера або ноутбука через стандартний порт USB 2.0. Вивчення зразків і обробка зображення відбувається за допомогою програми захоплення зображення, що входить у стандартну комплектацію. Крім запису і редагування фотографій і відео, за допомогою програми можна виміряти довжину об'єкта, периметр, радіус, діаметр, а також різноманітні кути;

- мікроскоп порівняння «Пеленг МС-4» використовується для проведення експертних та ідентифікаційних досліджень у криміналістиці і судовій медицині. Програмне забезпечення мікроскопа дозволяє отримувати, обробляти, досліджувати й архівувати відеозображення. Управління роботою освітлювачів і моторизованим переміщенням столиків можливо як із панелі мікроскопа, так і з комп’ютера, підключеного до мікроскопа;

- камера для досліджень відбитків, оброблених нінгідрином або DFO, призначена для дослідження прихованих відбитків пальців, залишених на папері та інших пористих 
поверхнях. Дослідження прихованих відбитків пальців, оброблених DFO, також можуть проводитись за допомогою системи BLUEMAXX ${ }^{\mathrm{TM}}$;

- лабораторна фумігаційна камера для обробки цианакрилатом FR600220 була сконструйована для обробки предметів, що мають непористу поверхню, методом цианакрилатного окурювання. Камера обладнана вхідним та вихідним портом, по одному з обох боків, що дозволяє використовувати такі аксесуари, як CYANOWAND ${ }^{\mathrm{TM}}$, та приєднувати iї до DeFumigator ${ }^{\mathrm{TM}}$ Cyanoacrylate Fume Extractor. Вхідний порт також дозволяє підключити портативний зволожувач PUM100, коли потрібно підвищити рівень вологості всередині камери.

Підрозділи Експертної служби $\mathrm{MBC}$ України у збиранні, обробці й аналізі дактилоскопічної інформації також використовують сканери відбитків пальців рук. Пристрої для читання відбитків пальців рук зараз знаходять різне застосування. Їх встановлюють на ноутбуки, в комп'ютерні миші, клавіатури, флешки, а також застосовують у вигляді окремих зовнішніх пристроїв і терміналів, що продаються в комплекті із системами AFIS (Automated fingerprint identification systems - системи автоматизованої ідентифікації відбитків пальців рук). Зокрема, використовуються 10-ти пальцеві прокатсканери відбитків пальців із технологією ідентифікації живої тканини і штучних відбитків (DERMALOG LF10), які відповідають стандартам CE, EC Directive 2001/95/ EC, EC Directive 2004/108/EC, EC Directive 2002/95/EC, EC Directive 2006/95/EC, FBI Appendix F, FBI WSQ, SGS (Liveness, Spoof and Fake Fingerprint Detection). Також для безконтактного зняття відбитків пальців шляхом фотографування працівники підрозділів Експертної служби МВС України використовують сучасні цифрові фотоапарати [5, c. 71$]$

Серед новітніх технологій у криміналістиці, які використовуються Експертною службою МВС України під час збирання, обробки й аналізу дактилоскопічної інформації, слід відзначити 3D-сканування (як приклад, використання 3D сканерів FARO®). Воно дозволяє прискорити процедуру дактилоскопіювання (сканер витрачає менше, ніж одну секунду, на палець); у подальшому розробники обіцяють збільшити його швидкість за рахунок сканування усіх десяти пальців за один раз. Відсутність контакту зі сканером зменшує забруднення поверхні скла або «змазання» відбитка через випадкове смикання пальцем, а отже, підвищує якість сканування. У базі даних відбиток зберігається у вигляді тривимірної моделі [6, c. 142].

Для дослідження загальних і окремих ознак використовуються різні програмні засоби. Наприклад, графічні редактори Photoshop, ACDSee та їх аналоги. Одною 3 істотних переваг, які вони надають, $€$ найширші можливості роботи 3 цифровими зображеннями слідів. Масштабування, обертання по осях, регулювання контрасту, яскравості, застосування різного роду фільтрів зображень, переведення в негативне зображення, накладення сітки, вимірювань лінійних і кутових величин і багато іншого, що, безумовно, полегшує проведення візуального дослідження. Значно спрощуються і підрахунок ліній, а також загальної кількості окремих ознак, створення розробки сліду. Оброблені за їх допомогою зображення зберігаються на носій інформації (жорсткий диск, флеш-пам'ять або оптичний диск), після чого з використанням уже текстового редактора вставляються в текст висновку експерта, або у фототаблицю [7, с. 68-69].

3 приводу можливостей запровадження цифрових технологій у процес збирання, обробки та аналізу таких біометричних даних у підрозділах Експертної служби МВС України, як ДНК зразків і ДНК профілів, варто відзначити, що в системі підрозділів Експертної служби МВС України функціонують ДНК-лабораторії, оснащені сучасним обладнанням, яке не поступається за своїми можливостями обладнанню лабораторій розвинутих країн Свропи. У таких лабораторіях функціонуе та регулярно поповнюється автоматизований облік генетичних ознак людини 3 метою подальшої перевірки [8, с. 175-176].

Так, збирання, обробка й аналіз генетичних ознак людини здійснюється за допомогою технічних приладів, які $є$ в ДНКлабораторії. Серед них:

- генетичний аналізатор ДНК, який є системою, призначеною для: високопродуктивного секвенування без залучення флуоресцентної детекції за рахунок послідовного подовження олігонуклеотидного ланцюга ДНК-полімеразою 3 одночасною реєстрацією виділення іонів водню в результаті вбудовування нуклеотидів; детектування зміни $\mathrm{pH}$ за допомогою напівпровідникових сенсорів і переведення даних у цифровий формат; секвенування клонально ампліфикованих фрагментів ДНК на поверхні мікрочастинок, поміщених в лунки зовнішнього шару одноразового напівпровідникового сенсорного мікрочіпа. Після первинної обробки одержуються дані у форматі FASTQ, BAM, SFF, VCF; 
- генетичний аналізатор ДНК / секвенатор - прилад, призначений для проведення реакцій секвенування та фрагментного аналізу, є валідованим відповідно до міжнародно визнаних стандартів DAB / SW GDAM в межах задач з ідентифікації особи у криміналістиці;

- секвенатор ДНК Ion Torrent PGM ${ }^{\mathrm{Tm}}$, який дає можливість отримувати високоякісні дані про послідовність ДНК за рекордні строки. Прилад може одночасно аналізувати більше десятка зразків менш ніж за 24 години Секвенатор ДНК IT PGM ${ }^{\text {тм }}$ дозволяє послідовно визначати конкретні ділянки геному різних організмів, шукати соматичні та спадкові мутації, аналізувати експресію генів і некодовані РНК, проводити метагеномний аналіз за послідовністю $16 \mathrm{~S}$ рРНК, а також аналіз взаємодій білка-ДНК (ChIP-Seq), Y-ДНК та мтДНК. Такі дані в рази підвищують ефективність встановлення особи трупа, підозрюваного або злочинця [9, с. 90];

- прилад 7500 Real Time PCR Systems з використанням набору реагентів Quantifiler Human для полімеразної ланцюгової реакції у реальному часі дозволяє визначити кількість виділеної ДНК, у тому числі за наявності інгібіторів, з метою подальшого проведення молекулярно-генетичних досліджень. Винятком є дослідження деградованої ДНК. Такі дослідження можна використовувати для проведення внутрішньої валідації в біологічних лабораторіях [10, с. 172-181].

Також сьогодні вирішується питання про закупівлю для підрозділів Експертної служби МВC України системи RapidHIT ID, що генерує лабораторно-якісні криміналістичні профілі ДНК усього за 90 хвилин (профілі STR створюються швидко за допомогою встановлених реактивів та інноваційного програмного забезпечення для повного контролю результатів) та 3500 Genetic Analyzer for Human Identification, що встановлює новий стандарт у капілярному електрофорезі для ідентифікації особи.

Оскільки у підрозділах Експертної служби МВС України функціонує така база біометричних даних, як облік голосів і мовлення людини, слід з'ясувати питання використання можливостей цифрових технологій під час збирання, обробки й аналізу таких біометричних даних. Зокрема, записи голосів і мовлення осіб, що передають повідомлення (у тому числі завідомо неправдиві) про загрозу безпеці громадян та інші суспільно небезпечні діяння, та голосів і мовлення осіб, щодо яких установлено факти передачі повідомлень (у тому числі завідомо неправдивих) про загрозу безпеці громадян та інші суспільно небезпечні діяння здійснюються черговими службами органів (підрозділів) Національної поліції України за допомогою системи багатоканального цифрового реєстратора документування мовленнєвої інформації на цифрових та аналогових лініях зв'язку. За допомогою вказаної системи забезпечується автоматичне документування всіх видів оперативних і диспетчерських переговорів посадових осіб у чергових службах органів (підрозділів) Національної поліції України. При цьому автоматичне документування забезпечується відкритими цифровими каналами з інтеграцією служб ISDN (Integrated Service Digital Networks), технічних засобів зв'язку, а також у разі потреби, в окремих випадках, фоноскопічних досліджень записів переговорів [11]. Відповідно запис голосів і мовлення анонімних і установлених осіб, які передають повідомлення (у тому числі завідомо неправдиві) про загрозу безпеці громадян та інші суспільно небезпечні діяння, полягає у фіксації на носій інформації за допомогою апаратно-програмних засобів запису та реєстрації мовленнєвої інформації змісту повідомлень, а також забезпеченні можливості їх накопичення та зберігання надалі. Отримані записи голосів і мовлення людини повинні бути якісними, тобто відповідати вимогам автоматизованих інструментальних методів ідентифікаційного дослідження голосу і мовлення та дозволяти проведення ідентифікації особи за голосом за допомогою автоматизованої системи «ДІАЛЕКТ» (програмне забезпечення «PHONEXI») 3 імовірністю ідентифікації не менше ніж 98-99 \% [11].

3 метою забезпечення збирання, обробки й аналізу записів голосів і мовлення людини у підрозділах Експертної служби МВС України використовуються цифрові апарати звукозапису, зазвичай цифрові диктофони, а також спеціалізовані програмно-апаратні засоби. Як приклад, програмний комплекс для ідентифікації людини за голосом та мовленням SIVEv.8.2 використовується для визначення та порівняння параметрів голосу мовця об'єктивним способом з метою відображення статистичного розподілу відповідних параметрів на діаграмах і розрахування коефіцієнту кореляції між цими діаграмами. Вказаний програмний комплекс дозволяє як здійснювати напівавтоматичний аналіз сигналів за допомогою різних методів, так і автоматичний пошук досліджуваного голосу в заданому наборі файлів, що містять зразки голосів. В. Г. Хахановський серед програмного забезпечення для автоматизації фоноскопічних досліджень відзначає АРМ «OTExpert», інструментальний комплекс аналізу і шумоочищення звукових сигналів 
«ИКАР» (Центр речових технологій); АРМ «МСР-Фоно», графічний інструментальний засіб для обробки та аналізу зображень «Pinguin-IP»; APM експерта-криміналіста «EXPAD»; програму «Signal Viei» [12, c. 96].

Тому не викликає жодних заперечень твердження Ю. О. Мазниченко 3 приводу того, що натепер методологія автоматизованого експертного дослідження звукових чи відеофайлів цифрового запису як об'єкта криміналістичного дослідження побудована на застосуванні спеціалізованих програмноапаратних засобів [13, с. 11-13]. Зокрема, в 2018 році була розроблена методика верифікації особи за фізичними параметрами мовленнєвих сигналів повідомлень, що містяться у голосовій базі даних, з використанням системи автоматичного пошуку «АВАТАР» [14].

\section{Висновки}

Отже, оптимізація процесу збирання, обробки та аналізу біометричних даних підрозділів Експертної служби МВС України неможлива без урахування досягнень науковотехнічного прогресу. Одним із напрямів удосконалення використання біометричних даних під час розслідування кримінальних правопорушень є запровадження цифрових технологій у процес збирання та накопичення біометричних даних, а також наповнення та використання баз біометричних даних. Використання підрозділами Експертної служби МВС України цифрових технологій у роботі з біометричними даними дозволить підвищити кількісні й якісні показники отриманих даних; зменшити витрати часу на їх збирання, дослідження та кримінальну реєстрацію; автоматизувати їх дослідження; підвищити ймовірність ідентифікації за ними особи.

\section{Список використаних джерел:}

1. Вдовиченко Ю.В. Цифрові технології як основа та рушійна сила розвитку сучасної глобальної економіки. Економіка та держава. 2018. № 1. C. 79-82.

2. Бахин В.П. Критерии и способы оценки криминалистических средств и методов, внедряемых в практику. Теория и практика собирания доказательной информации техническими средствами на предварительном следствии. Киев, 1980. С. 36-41.

3. Заруцький В.А. Автоматизація проведення експертних досліджень. Криміналістичний вісник. 2015. № 1 (23). С. 93-98.

4. Мокляк А.С. Біометрика у криміналістиці як один із методів покращення розслідування та розкриття злочинів. Вісник ОНДІСЕ. 2019. Випуск 5. С. 133-137.

5. Шевченко С.М. Деякі аспекти дактилоскопіювання. Вісник ОНДІСЕ. 2018. Випуск 4. C. 68-76.
6. Непорада А.С. Новітні технології в криміналістиці: 3D-скануванння під час огляду місця події. Криміналістичний вісник. 2016. № 2 (26). C. 141-143.

7. Бочарова О.С., Буржинский В.А. Лысянный Ю.Ю., Ревинский В.В. Вопросы идентификации по отпечаткам пальцев, решаемых в автоматизированных системах, используемых в судебной экспертизе. Актуальні питання стандартизаиії судово-експертного забезпечення правосуддя в Украйні. Перспективи розвитку: мат-ли міжнар. наук.-практ. конф., присв. 105-річчю судової експертизи в Україні та 95-річчю з дня народження академіка М. Я. Сегая (м. Київ, 4-5 липня 2018 р.) / за заг. ред. О.Г. Рувіна; уклад. Нестор Н.В., Полтавський А.О., Юдіна О.В., Форіс Ю.Б. Київ : КНДІСЕ Мінюст. України, 2018. С. 68-71.

8. Матарикіна О.В. Актуальність та можливості судової молекулярно-генетичної експертизи при ідентифікації осіб. Актуальні питання стандартизації судово-експертного забезпе чення правосуддя в Україні. Перспективи розвитку: мат-ли міжнар. наук.-практ. конф., присв. 105-річчю судової експертизи в Україні та 95-річчю з дня народження академіка М. Я. Сегая (м. Київ, 4-5 липня 2018 р.) / за заг. ред. О.Г. Рувіна; уклад. Нестор Н.В., Полтавський А.О., Юдіна О.В., Форіс Ю.Б. Київ : КНДІСЕ Мінюст. України, 2018. C. $174-176$.

9. Romanchuk S., Dombrovskiy I. NGS sequencing as a new method of forensic identification. The Ukrainian Biochemical Journal. 2017. Vol. 89. Issue 3. May-June. P. 90

10. Домбровський I.В., Повх А.С., Петричук С.В., Романчук С.М. Валідація методу кількісного та якісного визначення ДНК з використанням набору реагентів Quantifiler Human для полімеразної ланцюгової реакції у реальному часі. Криміналістичний вісник. 2017. № 1 (27). C. $172-183$.

11. Про затвердження документів щодо упровадження нових засобів зв'язку в телекомунікаційних мережах органів внутрішніх справ України : наказ Міністерства внутрішніх справ від 15.10.2009 № 444 // База даних «Законодавство України». URL: https://zakon.rada.gov.ua/rada/ show/v0444320-09?lang=uk (дата звернення: 09.10.2019).

12. Хахановський В.Г. Автоматизація судових експертних досліджень. Інформація і право. 2013. № 2 (8). C. 92-97.

13. Мазниченко Ю.О. Методологічні аспекти автоматизованого дослідження матеріалів та засобів цифрового звукозапису. Сучасні криміналістичні експертизи в розслідуванні злочинів : матеріали «круглого столу» (Київ, 25 лютого 2015). Київ : Нац. акад. внутр. справ, 2015. С. 9-14.

14. Рибальський О.В., Журавель В.В., Соловьев В.И. Методика верифікації особи за фізичними параметрами мовленнєвих сигналів повідомлень, що містяться у голосовій базі даних, 3 використанням системи автоматичного пошуку «АВАТАР» Київ, 2018. 44 с. 
The article states that one of the areas of improvement in the use of biometric data in criminal investigations is the introduction of digital technologies in the collection and accumulation of biometric data, as well as the filling and use of biometric databases. The possibilities of introduction of digital technologies during the collection, processing and analysis of biometric data in the units of the Expert Service of the Ministry of Internal Affairs of Ukraine are determined. It is found that the units of the Expert Service of the Ministry of Internal Affairs of Ukraine also use fingerprint scanners when collecting, processing and analyzing fingerprint information. Fingerprint readers are now widely used. They are installed on laptops, computer mice, keyboards, flash drives, and are used as separate peripherals and terminals, sold complete with AFIS systems. It is determined that different software tools are used to study common and individual features. One of the significant advantages they provide is the broadest ability to work with digital image traces. Scaling, rotating axes, adjusting contrast, brightness, applying various filters of images, translating into negative images, overlaying grids, measuring linear and angular values, and much more, which certainly facilitates visual exploration. The calculation of the lines, as well as the total number of individual features and the creation of the track development are greatly simplified. It is concluded that optimization of the process of collecting, processing and analysis of biometric data of the units of the Expert Service of the Ministry of Internal Affairs of Ukraine is impossible without taking into account the achievements of scientific and technological progress. One of the areas of improvement in the use of biometric data in criminal investigations is the introduction of digital technologies in the collection and accumulation of biometric data, as well as the filling and use of biometric databases. Using the units of the Expert Service of the Ministry of Internal Affairs of Ukraine of digital technologies in work with biometric data will allow to increase quantitative and qualitative indicators of the received data; reduce time spent on their collection, research and criminal registration; automate their research; increase the likelihood of identifying them.

Key words: database of biometric data, Expert Service of the Ministry of Internal Affairs of Ukraine, information and reference support of investigation, digital technologies, collection, processing, analysis. 